\title{
Removal of milk fat globules from whey protein concentrate $34 \%$ to prepare clear and heat-stable protein dispersions
}

\author{
Gang Liu and Qixin Zhong ${ }^{1}$ \\ Department of Food Science and Technology, The University of Tennessee, Knoxville 37996
}

\begin{abstract}
Whey protein concentrates (WPC) are low-cost protein ingredients, but their application in transparent ready-to-drink beverages is limited due to turbidity caused by fat globules and heat instability. In this work, fat globules were removed from WPC $34 \%$ (WPC-34) to prepare heat-stable ingredients via the Maillard reaction. The removal of fat globules by acid precipitation and centrifugation was observed to be the most complete at $\mathrm{pH} 4.0$, and the loss of protein was caused by micrometer-sized fat globules and protein aggregates. Spray-dried powder prepared from the transparent supernatant was glycated at $130^{\circ} \mathrm{C}$ for 20 and 30 min or $60^{\circ} \mathrm{C}$ for 24 and $48 \mathrm{~h}$. The 2 groups of samples had comparable heat stability and degree of glycation, evaluated by free amino content and analytical ultracentrifugation, but high-temperature, short-time treatment reduced the color formation during glycation. Therefore, WPC-34 can be processed for application in transparent beverages.
\end{abstract}

Key words: whey protein concentrate $34 \%$, milk fat globule, acid precipitation, glycation for heat stability

\section{INTRODUCTION}

Whey protein ingredients have high contents of EAA and versatile functionalities enabling various applications in the food industry (Vardhanabhuti et al., 2009). Whey protein concentrate 34\% (WPC-34) is a cost-effective ingredient with about $34 \%$ mass being proteins. When compared with WPC-80 and whey protein isolate (WPI), fewer purification steps are used in the production of WPC-34 and, therefore, WPC34 contains big particulates such as milk fat globules (MFG) that cause turbidity and precipitation (Hwang and Damodaran, 1995). Conversely, recent studies have found that the MFG membrane (MFGM) contains abundant bioactive lipids and proteins that have the potential of inhibiting the growth of cancer cells, lower-

Received June 3, 2014

Accepted June 28, 2014.

${ }^{1}$ Corresponding author: qzhong@utk.edu ing cholesterol, inhibiting pathogens, and assisting in the cure of Alzheimer's disease (Kanno, 1990; Spitsberg, 2005). The MFGM has excellent surface activities and can be applied as the carrier material to deliver bioactive ingredients in functional foods (Thompson and Singh, 2006; Thompson et al., 2006). Therefore, processes separating WPC to fractions with and without MFGM may add value to the dairy industry.

Hwang and Damodaran (1995), Damodaran (2010), and Damodaran (2011) selectively precipitated MFGM using various approaches. In an early study (Hwang and Damodaran, 1995), chitosan was used to form complexes with MFGM in Cheddar cheese whey at $\mathrm{pH}$ 4.5 , and the complexes were removed by centrifugation to form transparent supernatants, resulting in $92 \%$ removal of lipids and $6.8 \%$ reduction of protein. In a later study, divalent cations at 0 to $50 \mathrm{mM}$ were studied to precipitate MFGM at $30^{\circ} \mathrm{C}$ and $\mathrm{pH} 5.2$ (Damodaran, 2010). Calcium and magnesium ions were ineffective, whereas complete precipitation was observed for zinc ions above $20 \mathrm{~m} M$. In the latest study, diafiltration of Cheddar cheese whey at $\mathrm{pH} 4.2$ and $35^{\circ} \mathrm{C}$ for 30 min was also observed to be effective in precipitating MFGM that was speculated to be caused by removal of calcium ions that are critical to the structure of MFGM (Damodaran, 2011). A loss of $14 \%$ protein was reported after diafiltration. These studies are important to produce whey protein ingredients in applications requiring visual clarity.

Transparent beverages are possible products containing whey protein ingredients. To produce readyto-drink beverages, thermal processing is needed to ensure microbiological safety and quality. For acidic beverages with $\mathrm{pH}<4.6$, thermal processing conditions are not regulated, and the beverage industry uses hotfill processes equivalent to heating at about $88^{\circ} \mathrm{C}$ for 2 min (Etzel, 2004). For products with $\mathrm{pH}>4.6$, UHT processing can be used (e.g., at $138^{\circ} \mathrm{C}$ for at least 8 s for dairy products; McGarrahan, 1982). Conversely, whey proteins are known to aggregate during heating, especially at acidity near the isoelectric point of whey proteins $(\sim \mathrm{pH} 5.0)$ when the net charge of proteins is low (Bryant and McClements, 1998; Baier and McClements, 2005). Glycation of whey proteins with reducing 
saccharides is an effective method to improve the stability of proteins against aggregation during heating, and we recently showed that WPI glycated with lactose at $80^{\circ} \mathrm{C}$ for $2 \mathrm{~h}$ enabled transparent dispersions at $\mathrm{pH} 3.0$ to 7.0 with 0 to $150 \mathrm{mM} \mathrm{NaCl}$ or $\mathrm{CaCl}_{2}$ after heating at $88^{\circ} \mathrm{C}$ for $2 \mathrm{~min}$ and $138^{\circ} \mathrm{C}$ for $1 \mathrm{~min}$ (Liu and Zhong, 2013). Because cheese whey and WPC contain lactose, whey protein-lactose conjugates can be produced by integration with the whey protein-manufacturing processes.

The first objective of the present study was to exploit a simple process to prepare transparent samples by acid precipitation of MFG from WPC-34 suspension. The second objective was to evaluate the heat stability and structure of clarified WPC (cWPC) and conjugates prepared from cWPC (gWPC).

\section{MATERIALS AND METHODS}

\section{Materials}

The WPC-34 was kindly donated by Grande Cheese Co. (Grande, WI). Precast $15 \%$ gradient polyacrylamide gels and protein markers (catalog no. 161-0375) were purchased from Bio-Rad Laboratories Inc. (Hercules, CA). Nile Blue A dye was obtained from Sigma-Aldrich Corp. (St. Louis, MO). Bovine serum albumin used in the protein assay was purchased from BioWorld LLC (Atlanta, GA). Other chemicals used in the present study were from either Thermo Fisher Scientific Inc. (Pittsburgh, PA) or Sigma-Aldrich Corp.

\section{Precipitation of MFG from WPC-34 Suspension}

The WPC-34 was hydrated at a powder concentration of $2 \%$ (wt/vol) in deionized water for about $2 \mathrm{~h}$ under mixing on a stir plate until no visible powder was observed. The suspension was adjusted to $\mathrm{pH} 2.5$ to 6.5 with $1.0 \mathrm{~N} \mathrm{NaOH}$ or $1.0 \mathrm{~N} \mathrm{HCl}$. After standing at ambient conditions $\left(21^{\circ} \mathrm{C}\right)$ for $4 \mathrm{~h}$, the samples were centrifuged for $15 \mathrm{~min}$ at $8,000 \times g$ (model Sorvall RC $5 \mathrm{~B}$ Plus; DuPont, Wilmington, DE). Both the supernatant and precipitates were collected for further analysis. To improve the removal of MFGM, the supernatant was further incubated at ambient conditions for another 24 $\mathrm{h}$ and centrifuged again at $4,000 \times g$ for $15 \mathrm{~min}$ at $10^{\circ} \mathrm{C}$. Then, the turbidity of the supernatant was compared for visual appearance by photographing and determining the absorbance at $600 \mathrm{~nm}$ (Evolution $201 \mathrm{UV}$-visible spectrophotometer; Thermo Scientific, Waltham, MA). The protein concentration in the supernatant was measured by the bicinchoninic acid method using an assay kit from Thermo Fisher Scientific Inc. (Rockford, IL), with BSA as a protein standard.

\section{Preparation of cWPC powder}

The WPC-34 powder was suspended in deionized water and processed as above for the treatment adjusting to $\mathrm{pH}$ 4.0. After centrifugation, the transparent supernatant was collected, adjusted to $\mathrm{pH} 7.0$ with 1.0 N NaOH, and spray-dried (model B-290; Büchi Labortechnik AG, Flawil, Switzerland). The spray dryer was operated at conditions as follows: an inlet air temperature set at $160^{\circ} \mathrm{C}$, a compressed air pressure of $600 \mathrm{kPa}$, an outlet temperature controlled at about $65^{\circ} \mathrm{C}$, an air flow rate of $32 \mathrm{~m}^{3} / \mathrm{h}$, and a feed flow rate of ca. $4 \mathrm{~mL} / \mathrm{min}$. The powder collected from the spray dryer was designated as cWPC and used in further experiments.

\section{SDS-PAGE}

The SDS-PAGE was carried out under the reducing conditions with a $15 \%$ precast polyacrylamide gel obtained from Bio-Rad Laboratories Inc. The WPC-34 was prepared at $2 \%(\mathrm{wt} / \mathrm{vol})$ concentration and then subjected to different treatments described in previous sections. Fifty microliters of each collected sample was mixed with $200 \mu \mathrm{L}$ of the SDS-PAGE loading buffer and then heated at $95^{\circ} \mathrm{C}$ for $5 \mathrm{~min}$ in a water bath. Five microliters of each sample was loaded into each well of gel. Electrophoresis in a Mini Protean Tetra Cell (BioRad Laboratories Inc.) was conducted at a constant voltage of $200 \mathrm{~V}$ and a current of $400 \mathrm{~mA}$ until the indicator dye reached the gel bottom. After staining with Coomassie Blue for $10 \mathrm{~min}$, the gel was destained until bands became visible.

\section{Characterization of Protein Particles and MFG by Confocal Laser Scanning Microscopy}

The microstructural characteristics of MFGM and protein were studied using a Leica SP2 confocal laser scanning microscope (Leica Microsystems GmbH, Mannheim, Germany). The instrument was equipped with an Argon ion laser excited at a wavelength of 633 $\mathrm{nm}$ for protein observation and a HeNe laser excited at $543 \mathrm{~nm}$ for fat observation. One milliliter of WPC sample $[2 \%(\mathrm{wt} / \mathrm{vol})$ powder suspended in distilled water at $\mathrm{pH} 7.0$ ] was mixed with $10 \mu \mathrm{L}$ of a $1.0 \%$ (wt/vol) Nile Blue A solution to stain both proteins and lipids before imaging.

\section{Fat, Protein, and Lactose Contents in WPC and cWPC}

The total lipid content was determined using the method of AOAC International (2012; method 989.05). 
The lactose content was determined using the phenolsulfuric acid method (Barnett and Tawab, 1957), with pure lactose as a standard. The total protein content was determined using the abovementioned bicinchoninic acid method. Duplicate samples were tested.

\section{Preparation of gWPC}

The spray-dried cWPC powder was placed in a container and applied to a layer with ca. 1-mm thickness. The container was then placed on a perforated plate in a desiccator, with a saturated $\mathrm{KBr}$ solution below the perforated plate to obtain $79 \%$ relative humidity (Akhtar and Dickinson, 2007). The desiccator containing the samples was incubated in an oven pre-equilibrated at $60^{\circ} \mathrm{C}$ for 24 and $48 \mathrm{~h}$ or at $130^{\circ} \mathrm{C}$ for 20 and 30 min to prepare gWPC.

\section{Free Amino Group Content}

The content of available free amino groups was quantified using a previously reported o-phthaldialdehyde (OPA) method (Nielsen et al., 2001) with slight modifications. The fresh OPA working solution was prepared by diluting the following mixtures to a total volume of $200 \mathrm{~mL}$ with deionized water: $2.5 \mathrm{~mL}$ of $20 \%$ (wt/vol) SDS, $25 \mathrm{~mL}$ of $100 \mathrm{~m} M$ sodium borate, 400 $\mu \mathrm{L}$ of $\beta$-mercaptoethanol, and $0.16 \mathrm{~g}$ of OPA dissolved in $4 \mathrm{~mL}$ ethanol. Fifty microliters of protein dispersions [with 1\% (wt/vol) powder] was mixed with $3 \mathrm{~mL}$ of the freshly prepared OPA working solution. The mixture was vortexed for $10 \mathrm{~s}$ and incubated for $2 \mathrm{~min}$ in the dark at ambient temperature $\left(21^{\circ} \mathrm{C}\right)$ before measuring the absorbance at $340 \mathrm{~nm}$ using an Evolution 201 UV-visible spectrophotometer (Thermo Scientific). The OPA working solution was used as a blank. Absorbance data were converted to free amino contents using a calibration curve established with 0.01 to $5.0 \%$ (wt/wt) L-lysine standard solutions. Triplicate measurements were conducted for each sample.

\section{Analytical Ultracentrifugation}

The molecular weights (MW) of WPC were characterized using a Beckman XL-I analytical ultracentrifuge (Beckman Coulter Inc., Palo Alto, CA). The dispersions were prepared at an overall protein concentration of $1.2 \mathrm{mg} / \mathrm{mL}$ and adjusted to $\mathrm{pH} 3.0$. The dispersions were filled into the standard double-sector cell and centrifuged at $182,000 \times g$ for $480 \mathrm{~min}$ at $25^{\circ} \mathrm{C}$. The UV absorbance data were collected at $280 \mathrm{~nm}$ every $4 \mathrm{~min}$ at $25^{\circ} \mathrm{C}$ and analyzed according to the Liu and Zhong (2013). The number of lactose molecules (n) glycated to 1 whey protein molecule was calculated from the small- est MW peak of sedimentation profiles (monomeric proteins) using the following equation:

$$
\mathrm{n}=\left(\mathrm{M}_{2}-\mathrm{M}_{1}\right) / \mathrm{M}_{3}
$$

where $\mathrm{M}_{1}, \mathrm{M}_{2}$, and $\mathrm{M}_{3}$ stand for the average $\mathrm{MW}$ of whey protein before glycation, whey protein conjugate, and lactose (342 Da), respectively.

\section{Heat-Stability Test}

Heat stability of WPC dispersions was assessed at $88^{\circ} \mathrm{C}$ for $2 \mathrm{~min}$ in a water bath, simulating the hot-fill process in the beverage industry (Etzel, 2004), or at $138^{\circ} \mathrm{C}$ for $1 \mathrm{~min}$ in a glycerol bath, simulating UHT processing (McGarrahan, 1982). The dispersions were prepared with powder concentration of $4 \%$ (wt/vol) and adjusted to $\mathrm{pH} 3.0$ to 7.0 with $1.0 \mathrm{M} \mathrm{NaOH}$ or 1.0 $M \mathrm{HCl}$ and 0 to $150 \mathrm{mM} \mathrm{NaCl}$. One or $2 \mathrm{~mL}$ of final dispersions was filled in 4-mL glass vials sealed with plastic caps for heat-stability tests.

\section{Color Determination}

The color of the protein dispersions was determined on a MiniScan XE Plus Hunter colorimeter (Hunter Associates Laboratory Inc., Reston, VA). Color parameters lightness $\left(\mathbf{L}^{*}\right)$, redness $\left(\mathbf{a}^{*}\right)$, and yellowness (b*) were determined for 10-mL samples with $4 \%$ (wt/ vol) powder. Duplicate analyses of the samples were conducted for each sample.

\section{Statistical Analysis}

Data were reported as mean \pm standard deviation from duplicates or triplicates. The statistical analysis was carried out using the SPSS 13.0 statistical analysis system (SPSS Inc., Chicago, IL). One-way ANOVA and a least significant difference test were used to compare statistical differences of the mean at a $P$-value of 0.05 .

\section{RESULTS AND DISCUSSION}

\section{Acid Precipitation of WPC-34 Suspensions}

Effects of $\mathrm{pH}(2.5-6.5)$ on precipitation properties of WPC-34 were first studied. After adjusting $\mathrm{pH}$ and incubation for $24 \mathrm{~h}$, precipitation was observed at all $\mathrm{pH}$ conditions, most significantly at $\mathrm{pH} 4.0$, followed by $\mathrm{pH} 4.1$ (Figure 1A). After centrifugation, the supernatants of these 2 samples had lower absorbance than other samples (Figure 1B) and were transparent (not shown). The protein content in the supernatants ranged from 0.425 to $0.561 \%$ (wt/vol), corresponding 
to 17.5 to $37.5 \%$ precipitation of total protein (Figure $1 \mathrm{C})$. The lowest protein content was at $\mathrm{pH} 4.0$, agreeing with the most precipitated MFG (Figure 1A). When analyzed using SDS-PAGE for selected samples (Figure 2 ), the precipitated mass had bands corresponding to major whey proteins such as $\beta-\mathrm{LG}, \alpha-\mathrm{LA}$, and BSA and differed slightly from the supernatant after centrifugation. Most notably, the band at around $100 \mathrm{kDa}$, corresponding to the heavy chain of IgG (Damodaran, 2010), was more intense in the precipitate (Figure 2) than in the supernatant (Figure 3). The supernatants obtained from the samples adjusted to different $\mathrm{pH}$ conditions showed similar SDS-PAGE profiles (Figure 3 ), indicating that $\mathrm{pH}$ did not have significant effects on the precipitation of major whey proteins.

The results suggest that transparent WPC dispersions can be obtained by precipitating MFG at appropriate acidity. It is likely that MFG in WPC-34 have a net charge close to 0 at $\mathrm{pH} 4.0$ and precipitate due to hydrophobic attraction (Damodaran, 2010). The observations agree with the fact that phosphate has a $\mathrm{pK}_{1}$ of $\mathrm{pH} 4.0$ and is the only ionizable group of MFGM phospholipids (Moncelli and Becucci, 1995; Damodaran, 2010). The optimum acidity of precipitating MFG (pH 4.0) in the present study is slightly different from an earlier study at pH 4.2 (Damodaran, 2011), possibly because of different starting materials and different precipitation temperatures $\left(21\right.$ vs. $\left.35^{\circ} \mathrm{C}\right)$. The loss of proteins during acidic precipitation was also higher than 6.8 to $14 \%$ observed by Hwang and Damodaran (1995), Damodaran (2010), and Damodaran (2011) who used liquid whey as the starting material. In our case, using commercial WPC-34, it is possible that some proteins were denatured during production and some were not hydrated sufficiently, which caused significant losses after precipitation and centrifugation, as evidenced by major whey proteins all present in the precipitate. The rest of this paper is based on samples precipitated and centrifuged at $\mathrm{pH}$ 4.0.

\section{Microstructures of WPC-34 Suspensions}

To further understand precipitation properties of WPC-34 suspensions, confocal laser scanning microscopy was used to characterize microstructures of particulates. As displayed in Figure 4, lipid particles contained a significant quantity of proteins, and some micrometer-sized protein particles were also present. The average diameter of the particles observed in microscopy was about $2.1 \mu \mathrm{m}$, with the biggest particle being ca. $3.6 \mu \mathrm{m}$. These particles are much bigger than the $<10$-nm size of individual whey protein molecules (Wang et al., 2013; Zhong et al., 2013), which are too small to be imaged by confocal laser scanning micros-
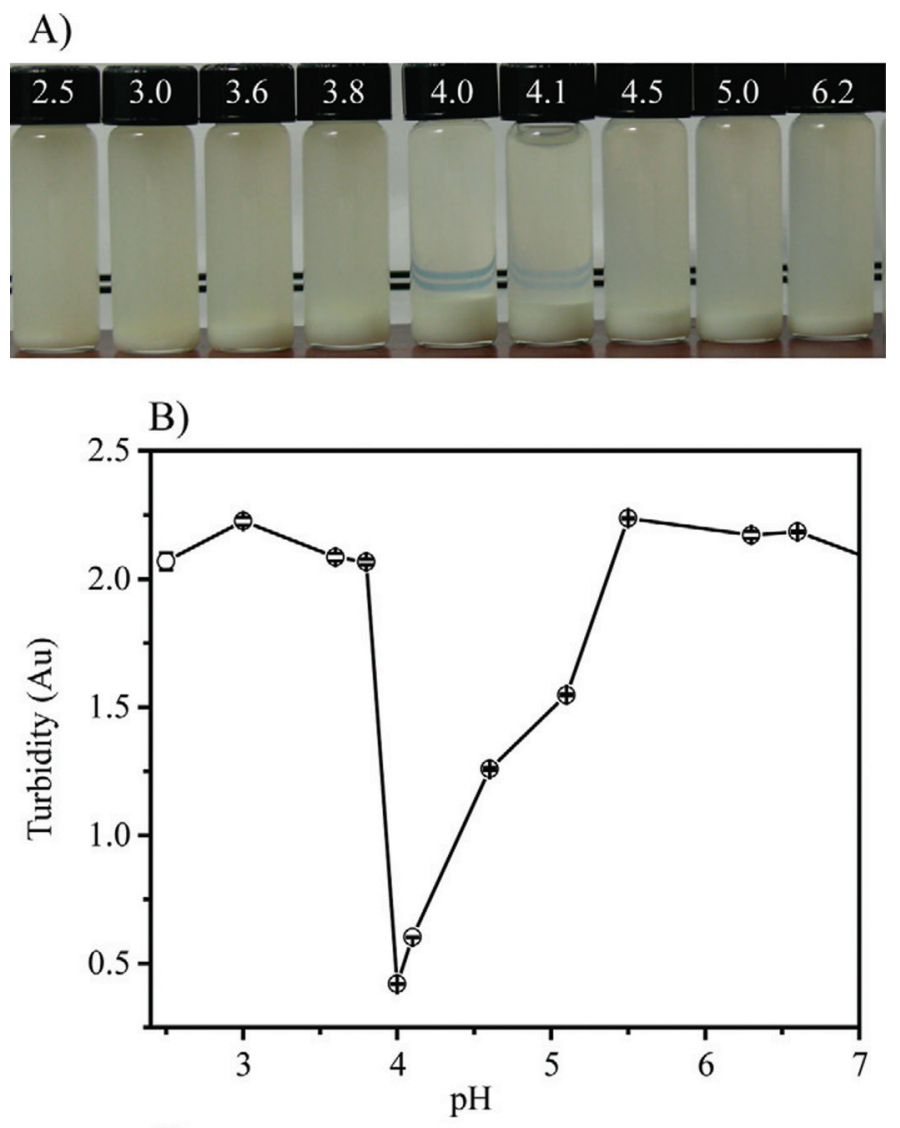

C)

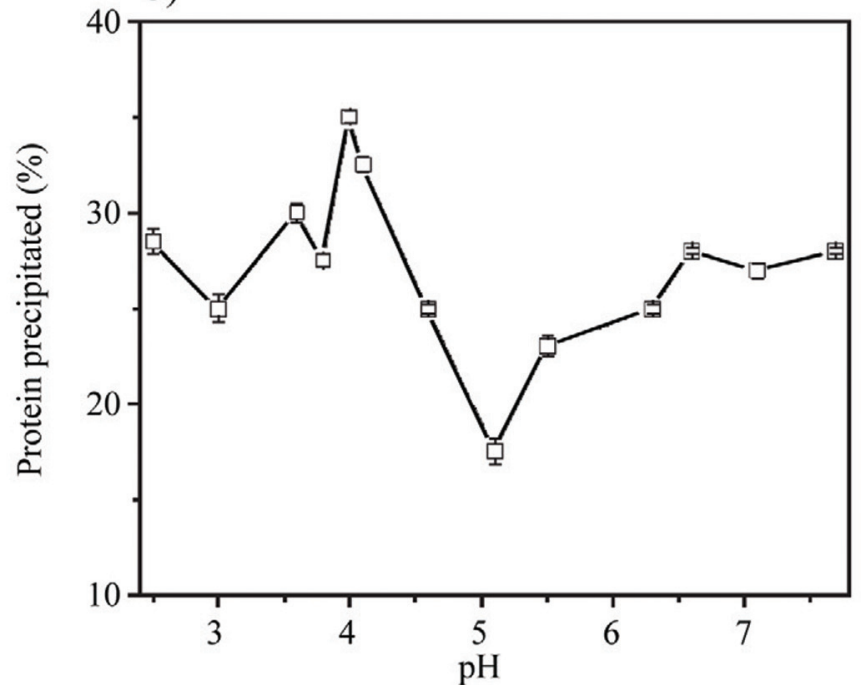

Figure 1. Appearance of suspensions with $2 \%$ (wt/vol) whey protein concentrate $34 \%$ (WPC-34) after adjusting to $\mathrm{pH}$ as shown on vial caps and incubation for $24 \mathrm{~h}$ at room temperature (A). Panels $\mathrm{B}$ and $\mathrm{C}$ show the absorbance and percentage of precipitated protein after centrifuging the samples at $4,000 \times g$ for $15 \mathrm{~min}$ at $10^{\circ} \mathrm{C}$. $\mathrm{Au}=$ absorbance units. Color version available in the online PDF.

copy. The protein microparticles likely are created due to denaturation and aggregation of proteins during cheese manufacturing and WPC production. Further- 


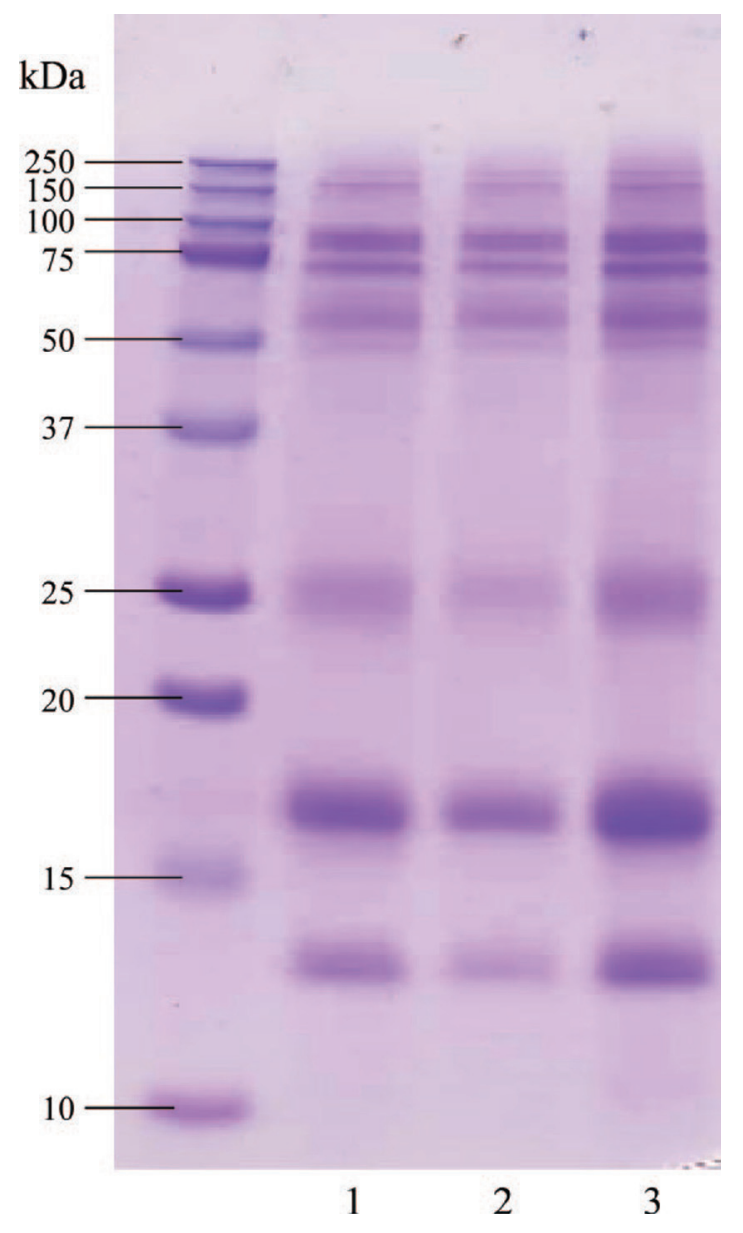

Figure 2. Sodium dodecyl sulfate PAGE analysis of the precipitated mass after $24 \mathrm{~h}$ incubation at $\mathrm{pH} 4.0$ (lane 1) and 3.6 (lane 2), with comparison with the precipitated mass after centrifuging the $\mathrm{pH}$ 3.5 sample (lane 3). Color version available in the online PDF.

more, the mean diameter of fat globules in raw milk is about $3.4 \mu \mathrm{m}$, which is reduced to about $0.6 \mu \mathrm{m}$ after homogenization (Walstra et al., 2005). Based on the dimension of particulates on microscopy images, the milk likely was homogenized. The fat globules likely had aggregated with some whey proteins, as observed in the SDS-PAGE, which showed significant amounts of whey proteins in the sediments (Figure 2).

\section{Compositional Changes of WPC-34 After Removing Fat Globules}

After removing MFG, the transparent supernatant was spray-dried to produce cWPC powder. The lipid content decreased from $3.30 \pm 0.71 \%$ in WPC-34 to $0.94 \pm 0.07 \%$ in cWPC. The protein content also decreased from $37.8 \pm 0.7 \%$ in WPC-34 to $35.2 \pm 0.9 \%$ in cWPC-34. This agreed with the presence of proteins in the precipitates (Figure 2). As lactose remained in the

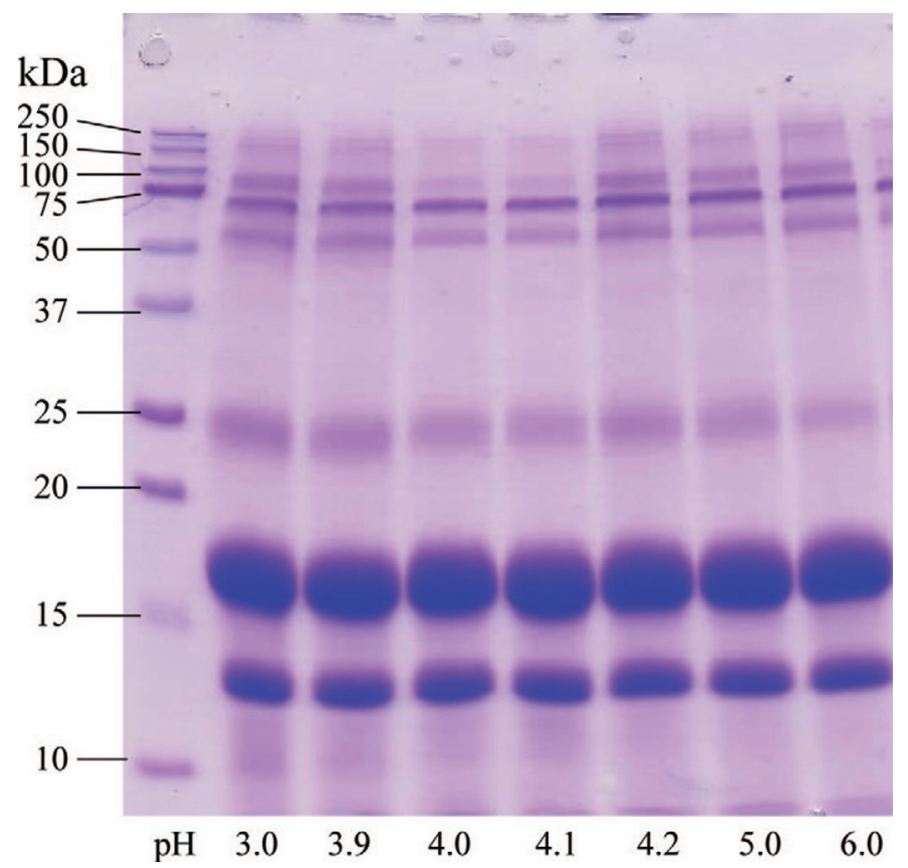

Figure 3. Sodium dodecyl sulfate PAGE analysis of the supernatants obtained after centrifuging $2 \%$ (wt/vol) whey protein concentrate $34 \%$ (WPC-34) suspensions adjusted to $\mathrm{pH} 3.0,3.9,4.0,4.1,4.2$, 5.0 , and 6.0 and incubated for $24 \mathrm{~h}$ at $21^{\circ} \mathrm{C}$. Color version available in the online PDF.

supernatant after precipitating fat globules, the content of lactose increased from $55.1 \pm 0.0 \%$ in WPC-34 to $63.8 \pm 1.5 \%$ in $\mathrm{cWPC}$.

\section{Heat Stability of Glycated cWPC}

After redispersing spray-dried cWPC at $4 \%$ (wt/vol) powder $[1.4 \%$ (wt/vol) protein], the dispersions were transparent at $\mathrm{pH} 3.0$ to 7.0 and 0 to $150 \mathrm{~m} M \mathrm{NaCl}$ (Figure 5A). After heating at $88^{\circ} \mathrm{C}$ for 2 min (Figure $5 \mathrm{~B}$ ) or $138^{\circ} \mathrm{C}$ for $1 \mathrm{~min}$ (similar appearance as Figure $5 \mathrm{~B}$; not shown), only the dispersion at $\mathrm{pH} 3.0$ with $\leq 50$ $\mathrm{m} M \mathrm{NaCl}$ remained transparent, whereas the other samples became turbid. For the gWPC prepared by heating the spray-dried cWPC powder at $60^{\circ} \mathrm{C}$ for 24 $\mathrm{h}$, the dispersions were clear at $\mathrm{pH} 3.0$ to 4.0 and 0 to $150 \mathrm{~m} M \mathrm{NaCl}$, and $\mathrm{pH} 5.0$ and 50 to $150 \mathrm{mM} \mathrm{NaCl}$ after heating at $88^{\circ} \mathrm{C}$ for $2 \mathrm{~min}$ (Figure $5 \mathrm{C}$ ). When the glycation at $60^{\circ} \mathrm{C}$ was extended to $48 \mathrm{~h}$, transparent dispersions were observed at $\mathrm{pH} 3.0$ to 7.0 and 0 to 150 $\mathrm{m} M \mathrm{NaCl}$ but had dark brown color (Figure 5D).

To decrease the color formation during glycation, 2 other gWPC samples were prepared at the same humidity but at a much higher temperature $\left(130^{\circ} \mathrm{C}\right)$ and a shorter duration (20 or $30 \mathrm{~min}$ ). Sample appearance after heating is shown in Figure $5 \mathrm{E}$ to $\mathrm{H}$, with the quantified color parameters presented in the next sec- 

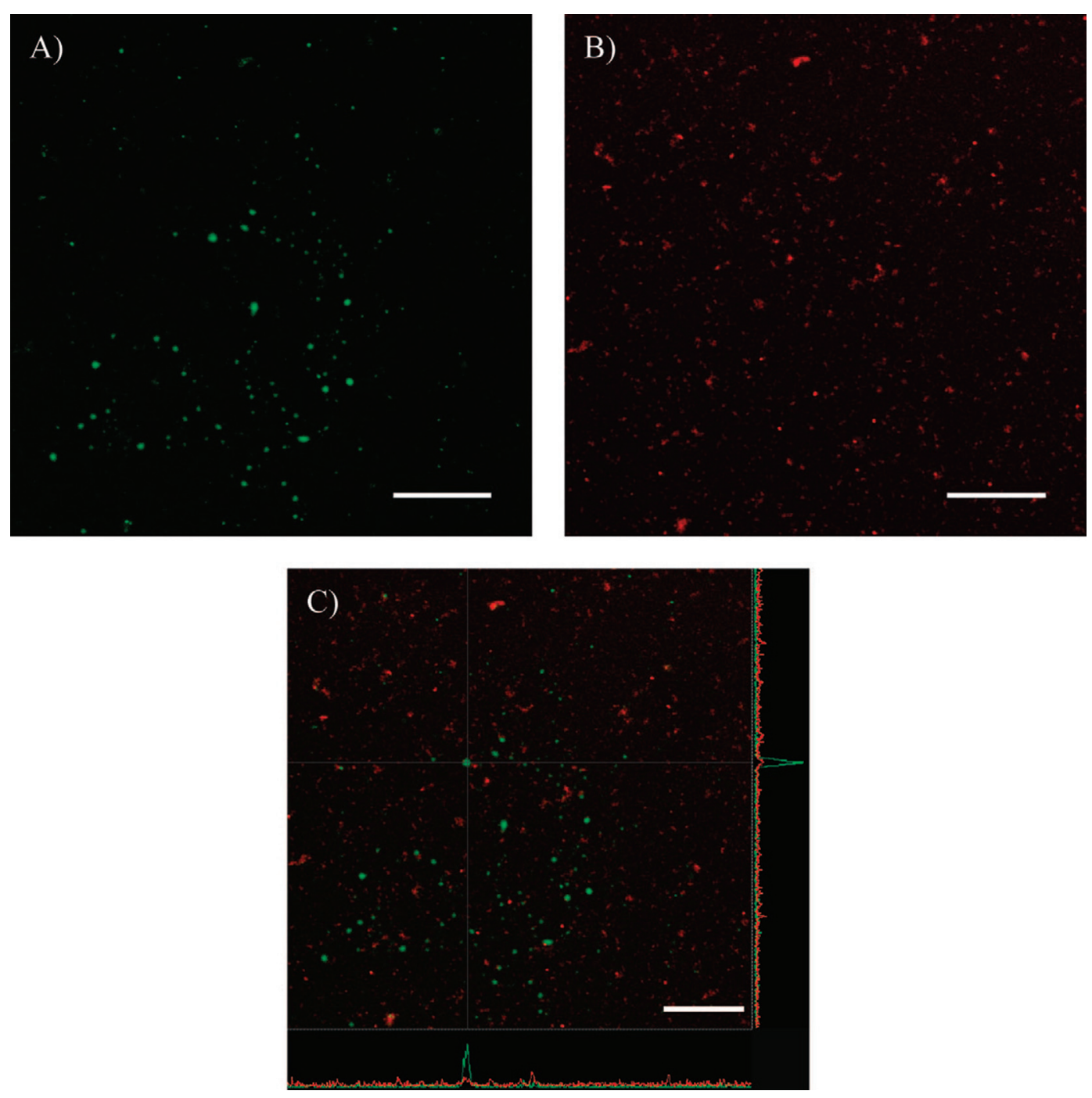

Figure 4. Confocal laser scanning microscopy images of whey protein concentrate $34 \%$ (WPC-34) suspension stained using Nile Blue A dye and excited at 633 and $543 \mathrm{~nm}$ to show proteins in green (A) and lipids in red (B), respectively. Scale bar $=35 \mu \mathrm{m}$. In the overlaid picture (C), the analysis is shown for an example of a fat globule with both proteins and lipids. Color version available in the online PDF.

tion. The gWPC prepared at $130^{\circ} \mathrm{C}$ for 20 min remained transparent after heating at $88^{\circ} \mathrm{C}$ for 2 min when dispersions were prepared with $4 \%$ (wt/vol) powder, $\mathrm{pH}$ 3.0 to 6.0 , and 0 to $150 \mathrm{mM} \mathrm{NaCl}$ or $\mathrm{pH} 7.0$ and $0 \mathrm{mM}$ $\mathrm{NaCl}$ (Figure 5E); after heating at $138^{\circ} \mathrm{C}$ for $1 \mathrm{~min}$ (Figure 5F), dispersions at $\mathrm{pH} 5.0$ and $0 \mathrm{mM} \mathrm{NaCl}, \mathrm{pH}$ 6.0 and $<100 \mathrm{mM} \mathrm{NaCl}$, and $\mathrm{pH} 7.0$ and 0 to $150 \mathrm{mM}$ $\mathrm{NaCl}$ became turbid. In contrast, the gWPC prepared at $130^{\circ} \mathrm{C}$ for 30 min became turbid only after heating the $\mathrm{pH} 7$ and 50 to $150 \mathrm{mM} \mathrm{NaCl}$ samples at $138^{\circ} \mathrm{C}$ for 1 min (Figure $5 \mathrm{G}$ and $\mathrm{H}$ ).

It is well known that the Maillard reaction involves multiple stages of reactions. The initial stage begins with a condensation reaction between the amino group of protein and the carbonyl group of reducing saccharides (van Boekel, 2006). The covalent attachment of reducing saccharides onto the protein could improve some functional properties of proteins (e.g., solubility, emulsification, foaming, and heat stability; Chevalier et al., 2001). The later stages of the Maillard reaction include the polymerization and degradation reactions originating from the Amadori rearrangement, and some advanced reaction products are responsible for the color formation (Ajandouz et al., 2001; Martins and Van Boekel, 2005; Liu and Zhong, 2012). The similar heat stability suggests similar degrees of conjugation at the initial stage of Maillard reaction for the gWPC produced at 2 temperatures $\left(130\right.$ vs. $\left.60^{\circ} \mathrm{C}\right)$ but different durations (20 or 30 min vs. 24 or $48 \mathrm{~h}$ ). The lighter color of $\mathrm{gWPC}$ produced at $130^{\circ} \mathrm{C}$ indicates the reduced later stages of reactions at a shorter time. This trend agrees with our earlier study where WPI was glycated with 


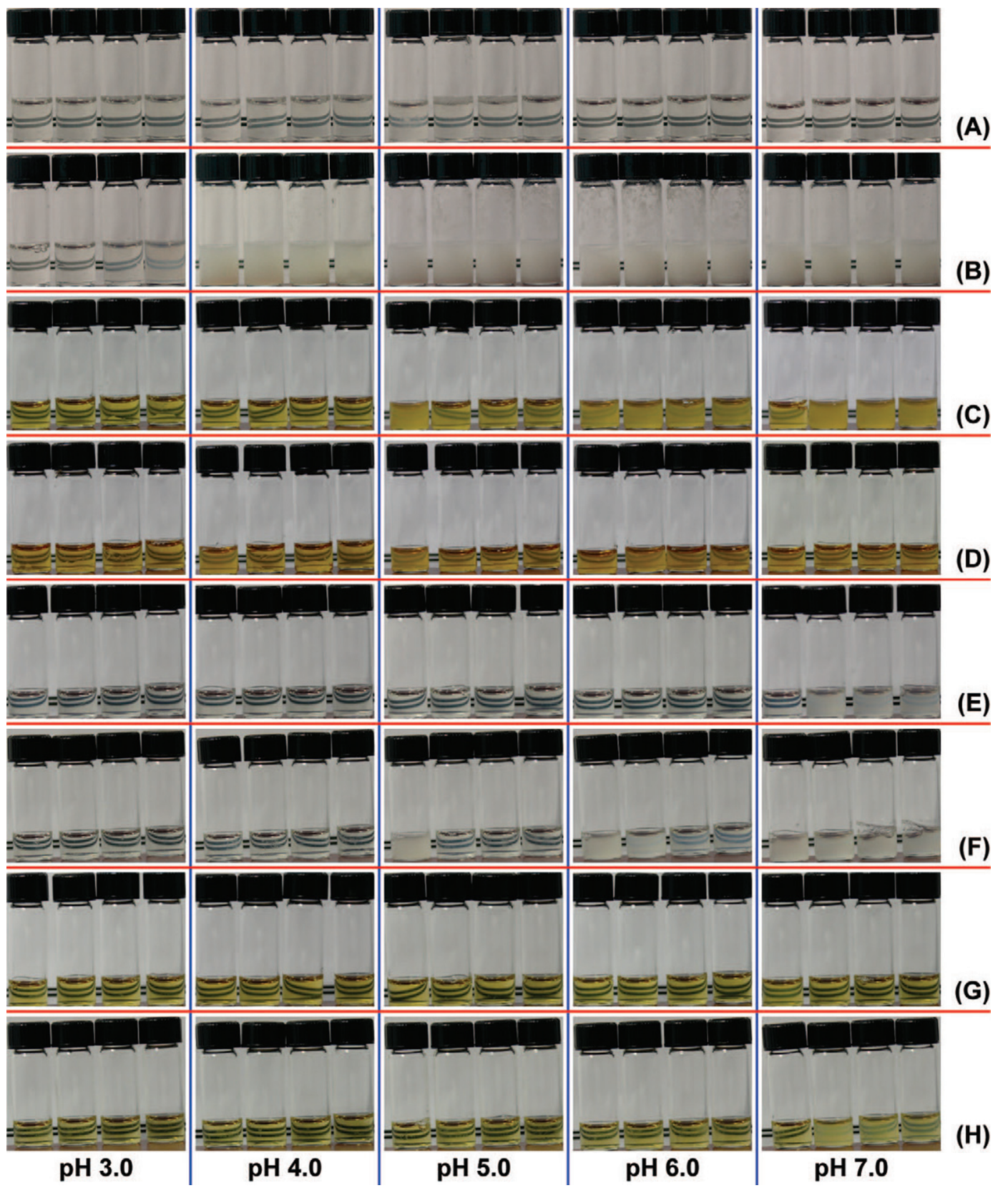

Figure 5. Appearance of aqueous dispersions of clarified whey protein concentrate (cWPC; A and B) and the conjugate $(\mathrm{C}-\mathrm{H})$ before $(\mathrm{A})$ and after heating at $88^{\circ} \mathrm{C}$ for $2 \mathrm{~min}\left(\mathrm{~B}, \mathrm{C}, \mathrm{D}, \mathrm{E}\right.$, and $\mathrm{G}$ ) or $138^{\circ} \mathrm{C}$ for $1 \mathrm{~min}(\mathrm{~F}$ and $\mathrm{H})$. The cWPC was prepared by precipitation at pH 4.0 , and the obtained supernatant was neutralized and spray-dried to produce powdered cWPC. The cWPC powder was glycated at $60^{\circ} \mathrm{C}$ for $24(\mathrm{C})$ and $48 \mathrm{~h}(\mathrm{D})$, or at $130^{\circ} \mathrm{C}$ for $20(\mathrm{E}$ and $\mathrm{F})$ and $30 \mathrm{~min}(\mathrm{G}$ and $\mathrm{H})$. All vials contained $4 \%$ (wt/vol) powder and were adjusted to $\mathrm{pH} 3.0$ to $7.0 \mathrm{with}$ $0,50,100$, and $150 \mathrm{mM} \mathrm{NaCl}$ (vials from left to right in each image) before the heat-stability test. Color version available in the online PDF

lactose, maltodextrin, or glucose at $60^{\circ} \mathrm{C}$ (for $24-72 \mathrm{~h}$ ) and $80^{\circ} \mathrm{C}$ (for $2 \mathrm{~h}$; Liu and Zhong, 2013). It was also noted that heat stability of $\mathrm{gWPC}$ at $\mathrm{pH} 7.0$ was not as good as lower $\mathrm{pH}$ when heated at $138^{\circ} \mathrm{C}$, which is different from WPI-lactose conjugates (Liu and Zhong, 2013) and opposite to the expectation that whey proteins should have more negative charges at $\mathrm{pH} 7.0$ and are expected to be more stable. We are not sure what caused this exception, as WPC and WPI production conditions are proprietary information. The structures of gWPC are presented below.

\section{Color Development in WPC Glycated at 60 or $130^{\circ} \mathrm{C}$}

The evolution of reddish-brown color of the samples is commonly used as an indicator for the progress of the 
Table 1. Color parameters of $4 \%$ (wt/vol) powder dispersions ( $\mathrm{pH} 7.0$ ) constituted with clarified whey protein concentrate (cWPC) and its conjugates prepared at various conditions ${ }^{1}$

\begin{tabular}{lccc}
\hline $\begin{array}{l}\text { Glycation } \\
\text { conditions }\end{array}$ & Redness $\left(\mathrm{a}^{*}\right)^{2}$ & Yellowness $\left(\mathrm{b}^{*}\right)^{3}$ & Lightness $\left(\mathrm{L}^{*}\right)^{4}$ \\
\hline None $(\mathrm{cWPC})$ & $-1.16 \pm 0.01^{\mathrm{e}}$ & $3.48 \pm 0.01^{\mathrm{e}}$ & $69.48 \pm 0.02^{\mathrm{a}}$ \\
$60^{\circ} \mathrm{C}$ for $24 \mathrm{~h}$ & $-1.76 \pm 0.03^{\mathrm{d}}$ & $23.84 \pm 0.22^{\mathrm{b}}$ & $66.26 \pm 0.03^{\mathrm{d}}$ \\
$60^{\circ} \mathrm{C}$ for $48 \mathrm{~h}$ & $-4.11 \pm 0.04^{\mathrm{a}}$ & $50.645 \pm 0.12^{\mathrm{a}}$ & $57.97 \pm 0.05^{\mathrm{e}}$ \\
$130^{\circ} \mathrm{C}$ for $20 \mathrm{~min}$ & $-2.09 \pm 0.03^{\mathrm{c}}$ & $8.705 \pm 0.02^{\mathrm{d}}$ & $68.71 \pm 0.02^{\mathrm{b}}$ \\
$130^{\circ} \mathrm{C}$ for $30 \mathrm{~min}$ & $-2.51 \pm 0.02^{\mathrm{b}}$ & $15.53 \pm 0.35^{\mathrm{c}}$ & $67.82 \pm 0.04^{\mathrm{c}}$ \\
\hline
\end{tabular}

${ }^{a}$ Different superscript letters within a column indicate significant differences in the mean $(P<0.05)$.

${ }^{1}$ Numbers are mean \pm SD from 2 replicates.

${ }^{2}$ Negative values indicate green and positive values indicate red.

${ }^{3}$ Negative values indicate blue and positive values indicate yellow.

${ }^{4} \mathrm{~L}^{*}=0$ yields black and $\mathrm{L}^{*}=100$ indicates diffuse white.

Maillard reaction (Bekedam et al., 2006). Table 1 lists the $\mathrm{L}^{*}, \mathrm{a}^{*}$, and $\mathrm{b}^{*}$ values of dispersions with $4 \%(\mathrm{wt} /$ vol) powder at $\mathrm{pH}$ 7.0, constituted with cWPC and its conjugates pretreated at various conditions. The most drastic increase for cWPC before and after glycation was the $b^{*}$ value, which represents the yellowness of the conjugate samples and the major color change (browning) during the Maillard reaction (Jaeger et al., 2010; Purlis, 2010). The browning was more significant at longer glycation duration and was less for samples glycated at $130^{\circ} \mathrm{C}$ than those at $60^{\circ} \mathrm{C}$. This observation, in agreement with the visual appearance (Figure 5 ), supports the discussion above that later stages of the Maillard reaction were not extensive during glycation at $130^{\circ} \mathrm{C}$ for a short time. The decrease in the $a^{*}$ and increase in $b^{*}$ values, as observed for all gWPC, indicate that the glycation process yielded the samples with less redness and darker appearance (Figure 5). The changes in $\mathrm{a}^{*}$ and $\mathrm{b}^{*}$ values were also found to correlate with glycation conditions, showing that HTST glycation resulted in smaller changes of both $\mathrm{a}^{*}$ and $\mathrm{b}^{*}$. As for the $\mathrm{L}^{*}$ value, although the improved solubility after glycation was observed to increase the $\mathrm{L}^{*}$ value (Akhtar and Dickinson, 2007), all conjugate treatments showed a reduced $\mathrm{L}^{*}$ value. This is likely because the cWPC is already transparent after removing MFGM. The advantage of short-time glycation at a high temperature, therefore, is significant in terms of reducing pigment formation (Table 1) while achieving heat stability (Figure 5).

\section{Structure of Glycated cWPC}

The free amino groups are reacted in the early stage of the Maillard reaction (Laroque et al., 2008; Gu et al., 2009). Thus, the loss of available amino groups can be used as an indicator to compare the degree of glycation. As shown in Table 2, the content of free amino groups decreased in all gWPC samples. No significant differences $(P>0.05)$ were observed for the glycation conditions of $60^{\circ} \mathrm{C}$ for $24 \mathrm{~h}$ and $130^{\circ} \mathrm{C}$ for $20 \mathrm{~min}$, as well as $60^{\circ} \mathrm{C}$ for $48 \mathrm{~h}$ and $130^{\circ} \mathrm{C}$ for $30 \mathrm{~min}$. The results in Table 2 verify the higher glycation rate at $130^{\circ} \mathrm{C}$ than at $60^{\circ} \mathrm{C}$. The data also generally agree with the heat stability of gWPC in Figure 5. The data further confirm that differences in color developments at the 2 different glycation temperatures are due to later stages of the Maillard reaction (Brands and van Boekel, 2002; Oliver et al., 2006).

Analytical ultracentrifugation was used to study molecular structures of cWPC and gWPC prepared at various conditions, with the sedimentation profiles shown in Figure 6 and the analyses listed in Table 3. After glycation at 60 or $130^{\circ} \mathrm{C}$, the smaller MW peak showed an increase in MW, which indicates the conjugation between lactose and protein. The portion of the higher MW peak area increased but the MW decreased after glycation (Figure 6; Table 3). The MW of the larger mass peak was more than twice of that of the smaller mass peak, which suggests the cross-linking of proteins during glycation, as previously reported (Jiménez-Castaño et al., 2005; Lillard et al., 2009; ter Haar et al., 2011). The reduced MW of the higher mass peak af-

Table 2. Contents of free amino group in clarified whey protein concentrate (cWPC) and its conjugates prepared at various conditions ${ }^{1}$

\begin{tabular}{lc}
\hline $\begin{array}{l}\text { Glycation } \\
\text { conditions }\end{array}$ & $\begin{array}{c}\text { Free amino } \\
\text { content }(\%)\end{array}$ \\
\hline None (cWPC) & $10.0 \pm 0.8^{\mathrm{a}}$ \\
$60^{\circ} \mathrm{C}$ for $24 \mathrm{~h}$ & $7.8 \pm 0.3^{\mathrm{b}}$ \\
$60^{\circ} \mathrm{C}$ for $48 \mathrm{~h}$ & $5.9 \pm 0.2^{\mathrm{c}}$ \\
$130^{\circ} \mathrm{C}$ for $20 \mathrm{~min}$ & $7.6 \pm 0.4^{\mathrm{b}}$ \\
$130^{\circ} \mathrm{C}$ for $30 \mathrm{~min}$ & $5.5 \pm 0.3^{\mathrm{c}}$ \\
\hline
\end{tabular}

$\overline{{ }^{a-c} \text { Different superscript letters within a column indicate significant dif- }}$ ferences in the mean $(P<0.05)$.

${ }^{1}$ Numbers are mean \pm SD from 2 replicates. 
Table 3. Molecular weight (MW) characteristics of clarified whey protein concentrate (cWPC) and its conjugates prepared at different conditions determined by analytical ultracentrifugation

\begin{tabular}{|c|c|c|c|c|c|}
\hline \multirow{2}{*}{$\begin{array}{l}\text { Glycation } \\
\text { conditions }\end{array}$} & \multicolumn{2}{|r|}{ Peak 1} & \multicolumn{2}{|r|}{ Peak 2} & \multirow{2}{*}{$\begin{array}{l}\text { No. of lactose } \\
\text { glycated } \\
\text { to protein }\end{array}$} \\
\hline & Area (\%) & Average MW (kDa) & Area $(\%)$ & Average MW (kDa) & \\
\hline None (cWPC) & 96.1 & 17.0 & 3.9 & 82.2 & - \\
\hline $60^{\circ} \mathrm{C}$ for $24 \mathrm{~h}$ & 90.6 & 18.2 & 9.4 & 81.7 & 3.5 \\
\hline $60^{\circ} \mathrm{C}$ for $48 \mathrm{~h}$ & 87.8 & 19.7 & 12.2 & 45.5 & 7.9 \\
\hline $130^{\circ} \mathrm{C}$ for $20 \mathrm{~min}$ & 90.4 & 19.0 & 9.6 & 77.9 & 5.8 \\
\hline $130^{\circ} \mathrm{C}$ for $30 \mathrm{~min}$ & 85.9 & 20.2 & 14.1 & 50.3 & 9.3 \\
\hline
\end{tabular}

${ }^{1}$ Calculated from peak 1 , based on the following equation: $n=(M 2-M 1) / M 3$, where $n=$ the number of lactose molecules glycated to 1 whey protein molecule and M1, M2, and M3 stand for the average MW of whey protein before glycation, whey protein conjugate, and lactose (342 Da), respectively.

ter glycation may be caused by the improved solubility of initially aggregated proteins in cWPC. Based on the smaller mass peak (monomeric proteins; Equation [1]), the number of lactose molecules glycated to each whey protein molecule was estimated to be 3.5 and 7.9 for glycation duration of 24 and $48 \mathrm{~h}$ at $60^{\circ} \mathrm{C}$, respectively, and that of gWPC prepared at $130^{\circ} \mathrm{C}$ for 20 and $30 \mathrm{~min}$ was 5.8 and 9.3 , respectively. The results are consistent with a previous study demonstrating multiple reducing saccharides bound to 1 whey protein molecule based on mass spectroscopy (Hiller and Lorenzen, 2010). Therefore, glycation of a sufficient number of lactose molecules on whey proteins is needed to obtain heat stability (Figure 5).

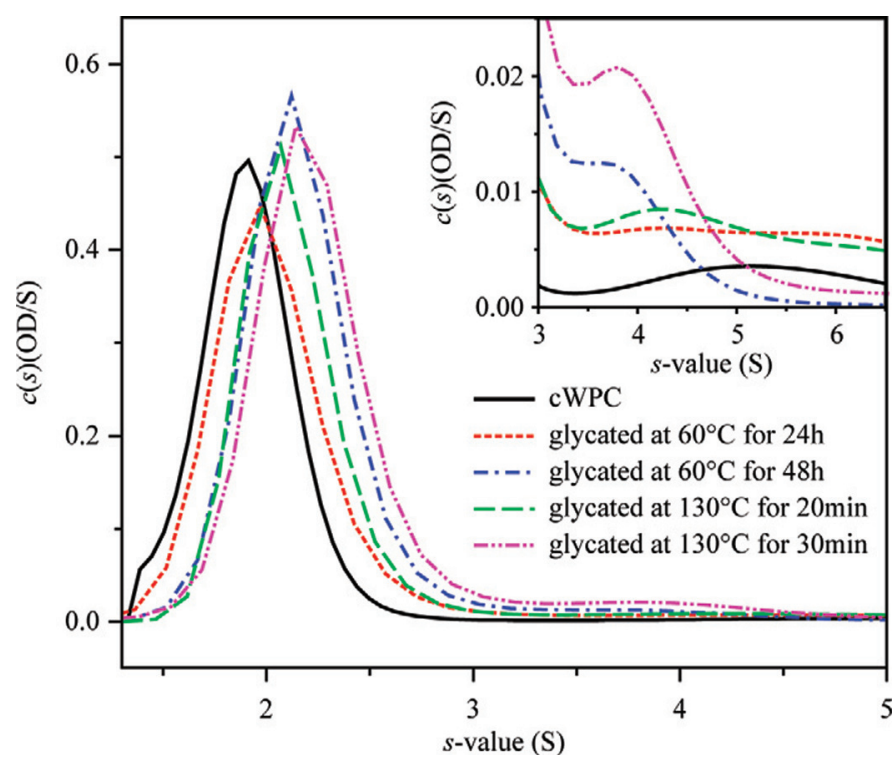

Figure 6. The best-fit sedimentation coefficient $[s$, in Svedberg unit $(\mathrm{S})]$ distributions $[c(s)]$ from analytical ultracentrifugation of clarified whey protein concentrate (cWPC; black solid line) and its conjugate dispersions constituted to $0.12 \%$ (wt/vol) protein and $\mathrm{pH} 3.0$. The zoom-in view of curves at $s$-values of 3.0 to $6.5 \mathrm{~S}$ is shown in the inset. OD = optical density. Color version available in the online PDF.

\section{CONCLUSIONS}

A simple approach was developed to prepare transparent whey protein samples from turbid WPC-34 by acid precipitation of MFG at ambient conditions followed by centrifugation. The optimal $\mathrm{pH}$ to produce the most transparent cWPC sample was observed at $\mathrm{pH}$ 4.0. The gWPC prepared from spray-dried cWPC powder showed the dramatically improved heat stability from cWPC at various acidic and ionic conditions. The conjugates prepared at $130^{\circ} \mathrm{C}$ for 20 and $30 \mathrm{~min}$ showed a lighter color but had similar heat stability enhancement compared with those prepared at $60^{\circ} \mathrm{C}$ for 24 and $48 \mathrm{~h}$, which agreed with comparable degrees of glycation. Findings from this study may be used to directly prepare protein ingredients from WPC-34 for applications such as transparent ready-to-drink protein beverages.

\section{ACKNOWLEDGMENTS}

This research was supported by the University of Tennessee and Dairy Research Institute (Rosemont, IL). We gratefully thank John Dunlap (Advanced Microscopy and Imaging Center, University of Tennessee, Knoxville) for the excellent technical support in confocal laser scanning microscopy, Yangchao Luo (Department of Food Science and Technology, University of Tennessee) for his editing, and Yongguang Guan (Department of Food Science and Technology, University of Tennessee) for determining protein, lipid, and lactose contents of WPC.

\section{REFERENCES}

Ajandouz, E. H., L. S. Tchiakpe, F. Dalle Ore, A. Benajiba, and A. Puigserver. 2001. Effects of $\mathrm{pH}$ on caramelization and Maillard reaction kinetics in fructose-lysine model systems. J. Food Sci. 66:926-931.

Akhtar, M., and E. Dickinson. 2007. Whey protein-maltodextrin conjugates as emulsifying agents: An alternative to gum arabic. Food Hydrocoll. 21:607-616. 
AOAC International. 2012. Official Methods of Analysis. 19th ed. AOAC International, Gaithersburg, MD.

Baier, S. K., and D. J. McClements. 2005. Influence of cosolvent systems on the gelation mechanism of globular protein: Thermodynamic, kinetic, and structural aspects of globular protein gelation. Comp. Rev. Food Sci. Food Safety 4:43-54.

Barnett, A. J. G., and G. A. Tawab. 1957. A rapid method for the determination of lactose in milk and cheese. J. Sci. Food Agric. $8: 437-441$.

Bekedam, E. K., H. A. Schols, M. A. J. S. van Boekel, and G. Smit. 2006. High molecular weight melanoidins from coffee brew. J. Agric. Food Chem. 54:7658-7666.

Brands, C. M. J., and M. A. J. S. van Boekel. 2002. Kinetic modeling of reactions in heated monosaccharide-casein systems. J. Agric. Food Chem. 50:6725-6739.

Bryant, C. M., and D. J. McClements. 1998. Molecular basis of protein functionality with special consideration of cold-set gels derived from heat-denatured whey. Trends Food Sci. Technol. 9:143-151.

Chevalier, F., J.-M. Chobert, Y. Popineau, M. G. Nicolas, and T. Haertlé. 2001. Improvement of functional properties of $\beta$-lactoglobulin glycated through the Maillard reaction is related to the nature of the sugar. Int. Dairy J. 11:145-152.

Damodaran, S. 2010. Zinc-induced precipitation of milk fat globule membranes: a simple method for the preparation of fat-free whey protein isolate. J. Agric. Food Chem. 58:11052-11057.

Damodaran, S. 2011. Straightforward process for removal of milk fat globule membranes and production of fat-free whey protein concentrate from cheese whey. J. Agric. Food Chem. 59:10271-10276.

Etzel, M. R. 2004. Manufacture and use of dairy protein fractions. J Nutr. 134:996S-1002S

Gu, F., J. M. Kim, K. Hayat, S. Xia, B. Feng, and X. Zhang. 2009 Characteristics and antioxidant activity of ultrafiltrated Maillard reaction products from a casein-glucose model system. Food Chem. 117:48-54.

Hiller, B., and P. C. Lorenzen. 2010. Functional properties of milk proteins as affected by Maillard reaction induced oligomerisation. Food Res. Int. 43:1155-1166.

Hwang, D.-C., and S. Damodaran. 1995. Selective precipitation and removal of lipids from cheese whey using chitosan. J. Agric. Food Chem. 43:33-37.

Jaeger, H., A. Janositz, and D. Knorr. 2010. The Maillard reaction and its control during food processing. The potential of emerging technologies. Pathol. Biol. (Paris) 58:207-213.

Jiménez-Castaño, L., M. Villamiel, P. J. Martín-Álvarez, A. Olano, and R. López-Fandiño. 2005. Effect of the dry-heating conditions on the glycosylation of $\beta$-lactoglobulin with dextran through the Maillard reaction. Food Hydrocoll. 19:831-837.

Kanno, C. 1990. Secretory membranes of the lactating mammary gland. Protoplasma 159:184-208.

Laroque, D., C. Inisan, C. Berger, É. Vouland, L. Dufossé, and F. Guérard. 2008. Kinetic study on the Maillard reaction. Consideration of sugar reactivity. Food Chem. 111:1032-1042.

Lillard, J. S., D. A. Clare, and C. R. Daubert. 2009. Glycosylation and expanded utility of a modified whey protein ingredient via carbohydrate conjugation at low pH. J. Dairy Sci. 92:35-48.
Liu, G., and Q. Zhong. 2012. Glycation of whey protein to provide steric hindrance against thermal aggregation. J. Agric. Food Chem. 60:9754-9762

Liu, G., and Q. Zhong. 2013. Thermal aggregation properties of whey protein glycated with various saccharides. Food Hydrocoll. 32:8796.

Martins, S. I. F. S., and M. A. J. S. Van Boekel. 2005. A kinetic model for the glucose/glycine Maillard reaction pathways. Food Chem. 90:257-269.

McGarrahan, E. T. 1982. Considerations necessary to provide for sterilized milk and milk products in hermetically sealed, nonrefrigerated containers. J. Dairy Sci. 65:2023-2034.

Moncelli, M. R., and L. Becucci. 1995. The intrinsic $\mathrm{p} K_{\mathrm{a}}$ values for phosphatidic acid in monolayers deposited on mercury electrodes. J. Electroanal. Chem. 385:183-189.

Nielsen, P. M., D. Petersen, and C. Dambmann. 2001. Improved method for determining food protein degree of hydrolysis. J. Food Sci 66:642-646.

Oliver, C. M., L. D. Melton, and R. A. Stanley. 2006. Glycation of caseinate by fructose and fructo-oligosaccharides during controlled heat treatment in the 'dry' state. J. Sci. Food Agric. 86:722-731.

Purlis, E. 2010. Browning development in bakery products-A review. J. Food Eng. 99:239-249.

Spitsberg, V. L. 2005. Invited review: Bovine milk fat globule membrane as a potential nutraceutical. J. Dairy Sci. 88:2289-2294.

ter Haar, R., Y. Westphal, P. A. Wierenga, H. A. Schols, and H. Gruppen. 2011. Cross-linking behavior and foaming properties of bovine $\alpha$-lactalbumin after glycation with various saccharides. J. Agric. Food Chem. 59:12460-12466.

Thompson, A. K., and H. Singh. 2006. Preparation of liposomes from milk fat globule membrane phospholipids using a Microfluidizer. J. Dairy Sci. 89:410-419.

Thompson, A. K., D. Haisman, and H. Singh. 2006. Physical stability of liposomes prepared from milk fat globule membrane and soya phospholipids. J. Agric. Food Chem. 54:6390-6397.

van Boekel, M. A. J. S. 2006. Formation of flavour compounds in the Maillard reaction. Biotechnol. Adv. 24:230-233.

Vardhanabhuti, B., U. Yucel, J. N. Coupland, and E. A. Foegeding. 2009. Interactions between $\beta$-lactoglobulin and dextran sulfate at near neutral $\mathrm{pH}$ and their effect on thermal stability. Food Hydrocoll. 23:1511-1520.

Walstra, P., J. T. M. Wouters, and T. J. Geurts. 2005. Dairy Science and Technology. 2nd ed. Taylor \& Francis Group LLC, Boca Raton, FL.

Wang, W., Q. Zhong, and Z. Hu. 2013. Nanoscale understanding of thermal aggregation of whey protein pretreated by transglutaminase. J. Agric. Food Chem. 61:435-446.

Zhong, Q., W. Wang, Z. Hu, and S. Ikeda. 2013. Sequential preheating and transglutaminase pretreatments improve stability of whey protein isolate at $\mathrm{pH} 7.0$ during thermal sterilization. Food Hydrocoll. 31:306-316. 